\title{
Gold-catalyzed propargylic substitutions: Scope and synthetic developments
}

\author{
Olivier Debleds, Eric Gayon, Emmanuel Vrancken \\ and Jean-Marc Campagne*
}

\author{
Review \\ Address: \\ Institut Charles Gerhardt, UMR 5253, Equipe AM2N, ENSCM 8 rue de \\ l'Ecole Normale, 34296 Montpellier Cédex, France \\ Email: \\ Emmanuel Vrancken - Emmanuel.Vrancken@enscm.fr; \\ Jean-Marc Campagne* - jean-marc.campagne@enscm.fr \\ * Corresponding author \\ Keywords: \\ direct substitutions; gold; isoxazolines; propargylic substitutions
}

Open Access

Beilstein J. Org. Chem. 2011, 7, 866-877.

doi:10.3762/bjoc.7.99

Received: 06 April 2011

Accepted: 08 June 2011

Published: 28 June 2011

This article is part of the Thematic Series "Gold catalysis for organic synthesis".

Guest Editor: F. D. Toste

(C) 2011 Debleds et al; licensee Beilstein-Institut.

License and terms: see end of document.

\begin{abstract}
This personal account summarizes our recent developments in gold-catalyzed direct substitutions on propargylic (allylic, benzylic) alcohols, with various nucleophiles (and bi-nucleophiles) based on the $\sigma$ - and/or $\pi$-acidity of gold(III) complexes. Synthetic developments are also briefly described.
\end{abstract}

\section{Introduction}

In the field of nucleophilic substitution reactions, leaving groups are mostly often obtained from alcohols but initially require their transformation to better leaving groups such as sulfonates or acetates. For economic, environmental and practical reasons it is therefore of interest to develop new experimental conditions for the direct substitution of activated alcohols such as tertiary, allylic, benzylic or propargylic ones [1-4]. Since some pioneering work using stoichiometric amounts of Lewis acid catalysts [3-5], much effort has been devoted to this goal. In this context, we have been particularly interested in the direct substitution of propargylic alcohols, because i) the presence of the alkyne function in the substitution product allows many further synthetic modifications, ii) the challenge of controlling the possible competition between substitutions at the propargylic and/or the allenic positions [6], and iii) compared to allylic and benzylic substitutions these reactions have been studied to a far lesser extent. Direct propargylic substitutions have traditionally and efficiently been carried out using the Nicholas [7] conditions but this implies the use of stoichiometric amounts of a cobalt complex. In 1994, Murahashi [8] described in a seminal paper the propargylic substitution of monosubstituted alkynes bearing a good leaving group on the propargylic alcohol moiety, where a mechanism through a copper-allenylidene intermediate was postulated. Subsequently, 
asymmetric versions have been described $[9,10]$. Thus, Hidai, Nishibayashi and Uemura developed a diruthenium complex catalyst for the direct substitution of monosubstituted propargylic alcohols $\left(\mathrm{R}^{3}=\mathrm{H}\right)$, by a large number of heteroatomic and carbon centered nucleophiles [11-15]. Enantiomerically pure ruthenium catalysts for asymmetric propargylic substitutions were next developed using acetone, hydrides and electron rich aromatics as nucleophiles [16-18]. In 2003, oxo-rhenium catalysts were introduced by Toste [19-21]. Substitution products were obtained in high yields with alcohols, allylsilanes, aromatic compounds and nitrogen nucleophiles. Interestingly, these reactions were not limited to monosubstituted propargylic alcohols [19-22].

In 2005, we described the direct $\mathrm{Au}$ (III)-catalyzed substitution of propargylic alcohols in the presence of various nucleophiles (allylsilanes, alcohols, thiols, electron rich aromatic compounds), and showed that gold probably acts as a Lewis acid to promote the formation of a stabilized propargylic carbocation intermediate $[23,24]$. A related reaction was subsequently reported by Dyker [25] in 2006, using azulene and 1,3dimethoxybenzene in Friedel-Crafts type reactions with benzylic and propargylic alcohols. Shortly after, Sanz and Zhan discovered, that these reactions could also be carried out under Brønsted acid and $\mathrm{FeCl}_{3}$ catalysis, respectively [26-29]. Later, the use of copper, indium, bismuth, scandium, ytterbium, phosphomolybdic acid and iodine catalysts were reported by several groups worldwide [30-39]. These aspects have been recently reviewed [40-43]. Among all these various Lewis acid catalysts, gold stands out since it possesses a unique hard/soft Lewis acid dichotomy allowing the activation of both alcohols and $\pi$-bonds. We therefore assumed that we could take advantage of this ambivalence in order to perform new domino processes $[44,45]$. Moreover, due to these ambivalent properties, the control of the chemo- and regioselectivity is challenging and raises interesting mechanistic considerations.

In this special issue dedicated to "Gold catalysis for organic synthesis", we would like to give a personal account on our work related to this topic: Scope, limitations and synthetic utilization of the gold(III)-catalyzed direct substitution of alcohols and the development of domino reactions.

\section{Review \\ Gold-catalyzed alcohol substitution Scope and limitations}

In the past few years, homogeneous gold catalysis has emerged as an efficient tool to activate triple bonds for the addition of various nucleophiles to alkynes. We initially anticipated that, through coordination to $\pi$-bond [46-48], gold catalysts may also act as propargylic alcohol-activating agents in propargylic substitutions (Scheme 1).

To validate this hypothesis, the reactivity of 1-phenyloct-2-yn1-ol (1a, $\mathrm{R}^{1}=\mathrm{Ph}, \mathrm{R}^{2}=\mathrm{H}, \mathrm{R}^{3}=n$-pentyl) with allyltrimethylsilane in the presence of various gold catalysts at room temperature was investigated (Scheme 2, Table 1). Gratifyingly, the reaction proved to be efficient with various $\mathrm{Au}(\mathrm{III})$ reagents (at $5 \%$ catalyst loading) (Table 1 , entries 1-4). The best results were observed with $\mathrm{NaAuCl}_{4} \cdot 2 \mathrm{H}_{2} \mathrm{O}$ (Table 1 , entry 1 ). In the presence of $\mathrm{Au}(\mathrm{I})$ catalysts (Table 1, entries 5 and 6), the results were more disappointing. Under the same reaction conditions (dichloromethane at room temperature), no reaction occurred in the presence of $\mathrm{PtCl}_{2}$ and $\mathrm{PdCl}_{2}(\mathrm{PhCN})_{2}$ catalysts.

Based on the results of these initial experiments, we set out to define the scope of these reactions by first examining variations on propargylic alcohols 1a-o. As illustrated in Scheme 2, the effect of the nature of the substituent on the acetylenic position ( $\mathrm{R}^{3}$ group, Scheme 2) was examined. The following trend was observed: $\mathrm{Ph}>$ alkyl $>\mathrm{SiR}_{3}>\mathrm{H}>>\mathrm{CO}_{2}$ Et. Indeed, the best yield (2b, 97\%) was obtained with propargylic alcohol $\mathbf{1 b}$ bearing a phenyl group and no reaction was observed when an electron-withdrawing group such as ester was present on the propargylic alcohol 1c. It is worth noting that with terminal alkynes, the product $\mathbf{2 d}$ was obtained in low yield (9\%). The presence of various substituted aromatic groups on the propargylic position ( $\mathrm{R}^{1}, \mathrm{R}^{2}$ groups), i.e., compounds $\mathbf{1 f}-\mathbf{1 j}$ (for other examples, see reference [24]) gave good product yields, whilst aryl groups with strong electron-withdrawing groups such as $p-\mathrm{NO}_{2} \mathbf{1 l}$ and $p-\mathrm{CF}_{3} \mathbf{1 k}$ were unreactive. When the aryl group was replaced by an alkyl chain, no reaction occurred (as illustrated with $\mathbf{1 m}$ ) whereas when two alkyl substituents were present, as in $\mathbf{1 n}$, the reactivity was restored to give $\mathbf{2 n}$ in $59 \%$ yield. When both an alkyl and an aromatic group were both

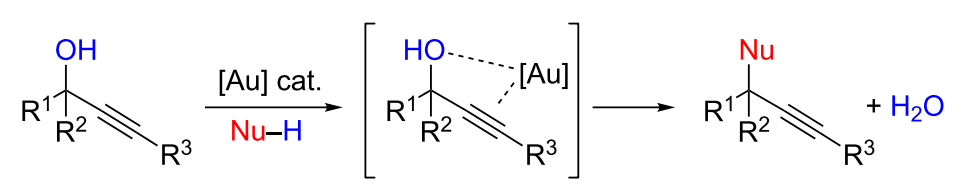




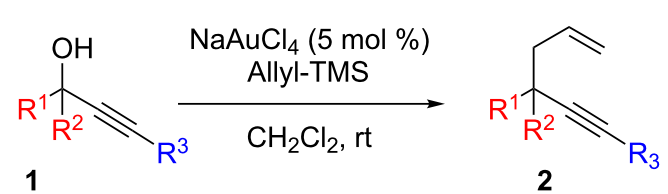

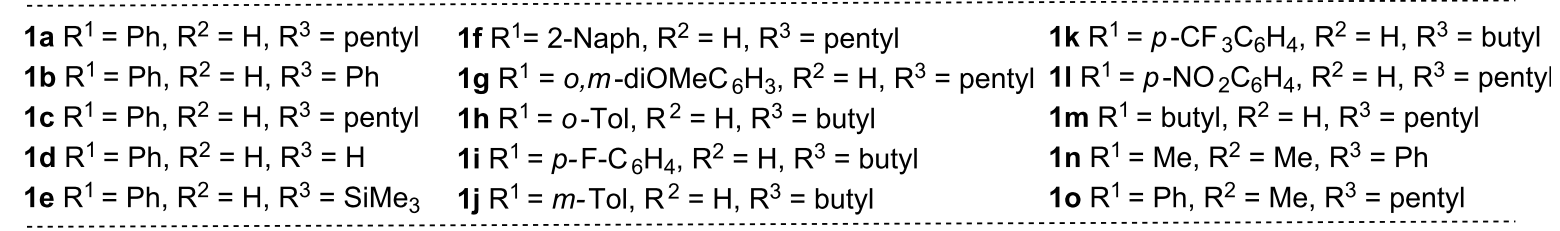<smiles>C=CCC(C#CC(C)C)c1ccccc1</smiles>

2a $82 \%$<smiles>C=CCC(C#Cc1ccccc1)c1ccccc1</smiles>

2b $97 \%$<smiles>C=CCC(C#CC(=O)OCC)c1ccccc1</smiles>

2c not observed (SM 1c recovered)<smiles>C#CC(CC=C)c1ccccc1</smiles>

2d $9 \%$<smiles>C=CCC(C#CCSC)c1ccccc1</smiles>

2e $71 \%$<smiles>C=CCC(C#CC(C)(C)C)c1cccc(OC)c1OC</smiles>

2g $85 \%$<smiles>C=CCC(C#CC(C)C)c1ccc(F)cc1</smiles>

2h $87 \%$

2i $88 \%$<smiles>C=CCC(C#CC(C)C)c1cccc(C)c1</smiles>

2j $81 \%$<smiles>C=CCC(C#CC)c1ccc(C(F)(F)F)cc1</smiles>

2k not observed (SM $1 \mathrm{k}$ recovered)<smiles>C=CCC(C#CC(C)C)c1ccc([N+](=O)[O-])cc1</smiles>

2I not observed (SM 11 recovered)<smiles>C=CCC(C#CC(C)C)C(C)C</smiles>

$2 \mathrm{~m}$ not observed

(SM $1 \mathrm{~m}$ recovered)<smiles>C=CCC(C)(C)C#Cc1ccccc1</smiles>

2n $59 \%$<smiles>C=CCC(C)(C#COP(C)O)c1ccccc1</smiles>

$2033 \%$

Scheme 2: Propargylic substitution: scope of substrates.

\section{Table 1: Catalyst screening.}<smiles>OCCOPC#CC(O)c1ccccc1</smiles>

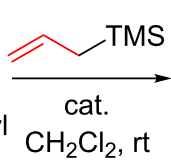<smiles>C=CCC(C)C#CPOC</smiles>

Entry Gold cat (\%) Time 2a Isolated (h) yield $(\%)$

\begin{tabular}{cccc}
\hline 1 & $\mathrm{NaAuCl}_{4} \cdot 2 \mathrm{H}_{2} \mathrm{O}(5)$ & 12 & 82 \\
2 & $\mathrm{AuBr}_{3}(5)$ & 12 & 68 \\
3 & $\mathrm{AuCl}_{3}(5)$ & 12 & 65 \\
4 & $\mathrm{HAuCl}_{4} \cdot 3 \mathrm{H}_{2} \mathrm{O}(5)$ & 12 & 60 \\
5 & $\mathrm{AuCl}(10)$ & 12 & 30 \\
6 & $\mathrm{Ph}_{3} \mathrm{PAuCl}(10)$ & 12 & $\mathrm{NR}^{\mathrm{a}}$ \\
7 & $\mathrm{PdCl}_{2}\left(\mathrm{PhCN}_{2}(5)\right.$ & 12 & $\mathrm{NR}^{\mathrm{a}}$ \\
8 & $\mathrm{PtCl}_{2}(5)$ & 12 & $\mathrm{NR}^{\mathrm{a}}$ \\
\hline
\end{tabular}

aNR = no reaction. present, as in 10, a lower yield was obtained due to rapid decomposition of the product $\mathbf{2 0}$ at room temperature. It should be emphasized that all the allyl substituted products $\mathbf{2 a - 2 0}$ have, in general, low stabilities and decompose within a few days at room temperature. Two general conclusions can be drawn from these experiments using allylsilanes as nucleophiles: A stabilization of a positive charge $(+$ or $\delta+$ ) on the propargylic position by electron-donating groups on the propargylic and/or acetylenic positions favors the reaction, and no product resulting from attack at the acetylenic position could be observed.

To explore further regioselectivity issues, compound $\mathbf{1 p}$, which is both an allylic and a propargylic alcohol, was submitted to the same reaction conditions. A 2:2:1 inseparable mixture of $S_{N}$ $\mathbf{2 p}$ and $\mathrm{S}_{\mathrm{N}}$ ' $\mathbf{2 q}$ and $\mathbf{2 r}$ products was obtained (Scheme 3).

The Au(III)-catalyzed reaction was next investigated for diverse series of nucleophiles. A large number of nucleophiles are very 


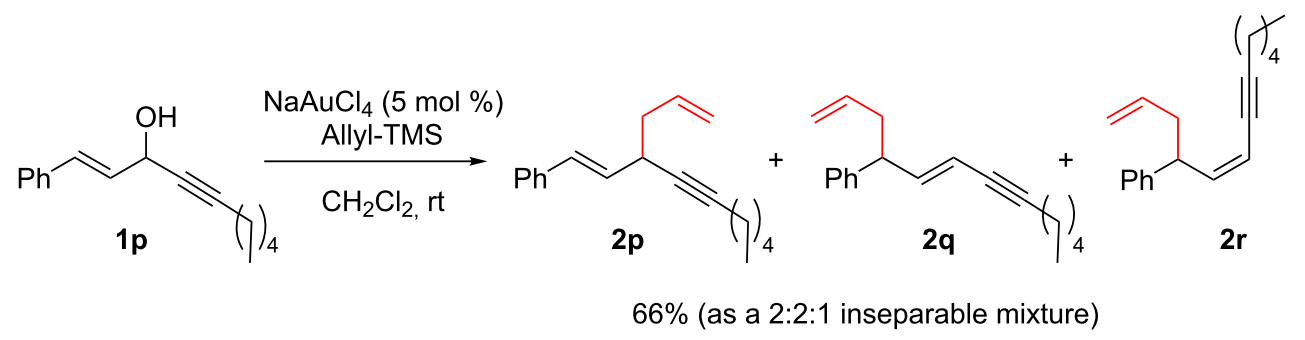

Scheme 3: Propargylic substitutions on allylic/propargylic substrates.

effective in these reactions including alcohols, thiols, hydrides (from $\mathrm{Et}_{3} \mathrm{SiH}$ or PMHS), electron-rich aromatic and heteroaromatic derivatives such as anisole or furan, and deactivated nitrogen nucleophiles such as phenylsulfonamide (compounds 3-8, Scheme 4).

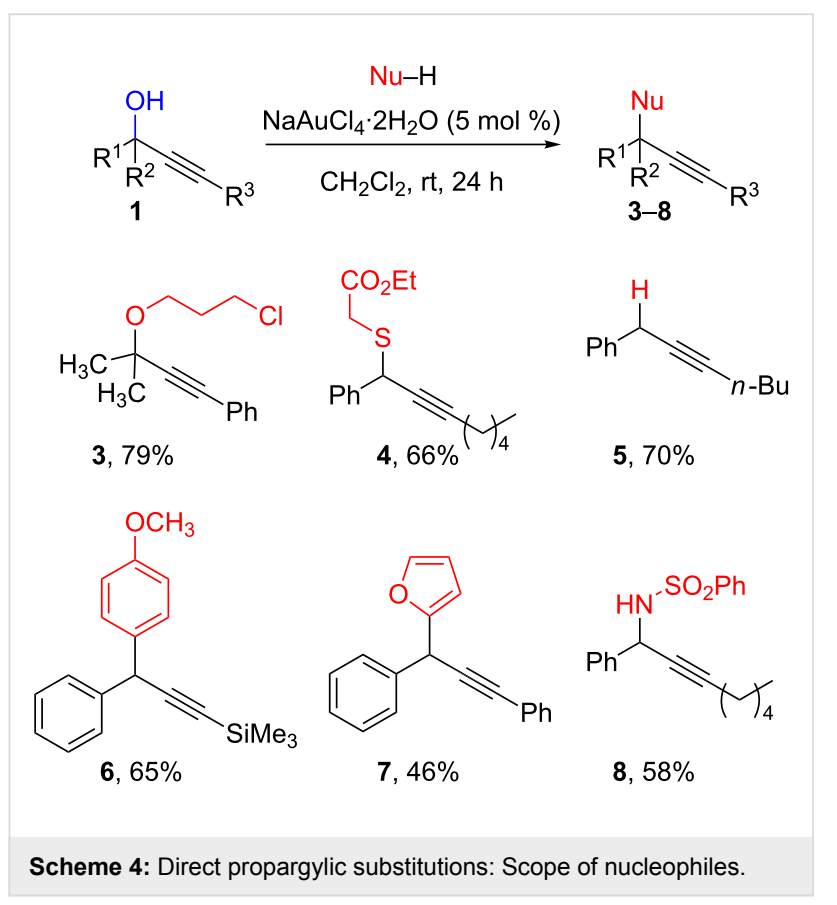

In some instances unexpected selectivities and further transformations were observed. When ethanol was used as the nucleophile, the corresponding Meyer-Schuster products [49-54], first observed by Utimoto [49], were selectively obtained as illustrated with the formation of compounds $\mathbf{9}$ and $\mathbf{1 1}$ (Scheme 5).

Interestingly, lowering the catalyst loading to $1 \mathrm{~mol} \%$, the substitution product $\mathbf{1 0}$ could be isolated in 60\% yield (along with $35 \%$ of the Meyer-Schuster product 11). This result could be explained by considering that $\mathbf{1 1}$ is derived from $\mathbf{1 0}$ through the conjugated addition of water (residual or produced during the substitution reaction) and a lower amount of gold catalyst should slow down the Meyer-Schuster process. It also suggests that, not only the $\mathrm{OH}$ group but also the OEt group can act as a good leaving group in these reactions. Indeed, when isolated compound 10 was subjected to $\mathrm{Au}(\mathrm{III})$ catalyst in the presence of water, $\mathbf{1 1}$ was obtained as the major product along with some unidentified by-products. Two consequences from these results are i) the use of an alcohol as nucleophile gives a product that can act as a substrate for further transformations (such as a Meyer-Schuster reaction), and ii) other ether ( $\mathrm{O}-\mathrm{Si}, \mathrm{O}-\mathrm{C})$ functions can be used in these reactions. Indeed, the use of silyl protected $\mathrm{OH}$ groups is possible as illustrated by our group (Scheme 6, reaction 1) and by the Kirsch group (Scheme 6, reaction 2) $[24,55]$. In both cases selective $S_{N}$ ' reactions were observed, not only with oxygen nucleophiles but also with<smiles>CC(C)(O)C#Cc1ccccc1</smiles>

$1 q$

\section{Ethanol}

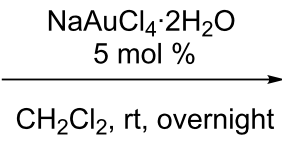

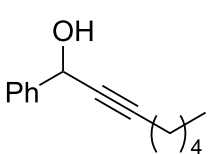

1a
Ethanol

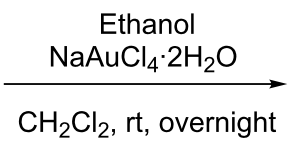

$5 \mathrm{~mol} \%$ cat $1 \mathrm{~mol} \%$ cat<smiles>CC(C)=CC(=O)c1ccccc1</smiles><smiles>CCOC(C#CC(C)(C)C)c1ccccc1</smiles>

10

11

$58 \%$ $35 \%$ 
<smiles>CC=CC=CC(C#CPC(C)(C)C)O[SnH3]</smiles>

$\mathrm{NaAuCl}_{4}, 2 \mathrm{H}_{2} \mathrm{O}(5 \mathrm{~mol} \%)$ $\mathrm{H}_{2} \mathrm{O} / \mathrm{MeOH} 1 / 9$

$\mathrm{rt}$<smiles>CS(=O)(=O)OC(C#CC=Cc1ccccc1)C=Cc1ccccc1</smiles>

14

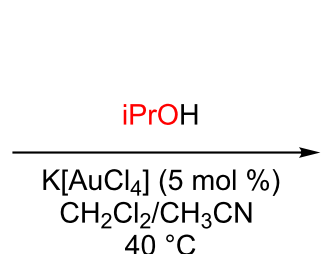<smiles>CCCCC#C/C=C/C=C/C(C)OC</smiles><smiles>CC(C)OC(/C=C/C#CPc1ccccc1)c1ccccc1</smiles>

$15,70 \%$ yield $(E: Z=1.3: 1)$

Scheme 6: Silyl-protected propargyl alcohols in propargylic substitutions

nitrogen and electron-rich aromatic nucleophiles [55]. It is worth noting that a mixture of $\mathrm{S}_{\mathrm{N}}$ and $\mathrm{S}_{\mathrm{N}}$ ' products was obtained when allylsilane was used as the nucleophile with related substrates (Scheme 3).

When acetylacetone was used as the nucleophile, no reaction occurred with $1 \mathbf{r}$ at room temperature, whereas in refluxing dichloroethane the substitution product $\mathbf{1 6}$ led to a mixture of products via triple bond hydration to give $\mathbf{1 7}[49,50,56]$ and furan formation to afford $\mathbf{1 8}$ (Scheme 7). The furan may possibly result from intramolecular addition of the enol form of acetylacetone. Related experiments have been independently reported by Arcadi [57].

The main limitations of the methodology appeared when azido $\left(\mathrm{TMSN}_{3}\right)$, amides and phosphorus centered nucleophiles were used as nucleophiles: In these cases, either decomposition products or dimerization to the ether product were observed [58].
As previously noted, the lack of reactivity when aryl substituents bearing electron-withdrawing groups are present either at the propargylic or acetylenic positions, or when the propargylic position is only substituted by one alkyl group, suggests that an $\mathrm{S}_{\mathrm{N}} 1$-type reaction is involved. To confirm this hypothesis, the reaction starting from enantiomerically pure $\mathbf{1 b}$ was carried out and the resulting substitution product $\mathbf{2 b}$ was shown to be the racemate (Scheme 8).

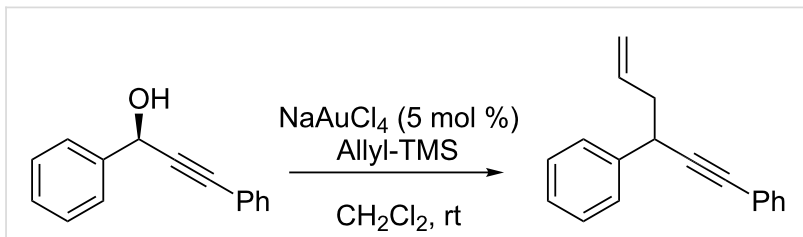

$(R)-1 \mathbf{b}, 96 \%$ ee

2b, $0 \%$ ee

Scheme 8: Enantiomerically enriched propargylic alcohols.<smiles>CCCCOC(O)C#CC(O)c1ccccc1</smiles><smiles>CC(=O)CC(C)=O</smiles><smiles>CC(=O)OC#CC(c1ccccc1)C(C(C)=O)C(C)=O</smiles><smiles>CCCCC(=O)CC(c1ccccc1)C(C(C)=O)C(C)=O</smiles>

$17,69 \%$<smiles>CCCCOCc1oc(C)c(C(C)=O)c1-c1ccccc1</smiles>

$18,26 \%$ 
This result showed that the presence of triple bond may be not necessary and prompted us to extend the methodology to other activated alcohols such as diarylmethanol, benzylic and allylic alcohols (Scheme 9) [24,59-61]. This reaction was further extended to tertiary alcohols by Asensio [62].
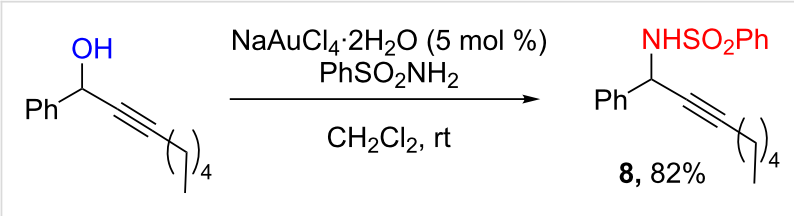

$\overbrace{\mathrm{Ph}}^{\mathrm{OH}}$
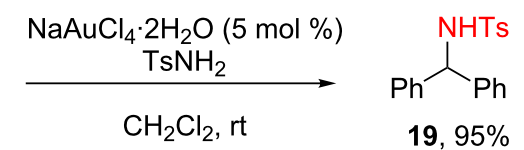

$\overbrace{\mathrm{Ph}}^{\mathrm{OH}}$
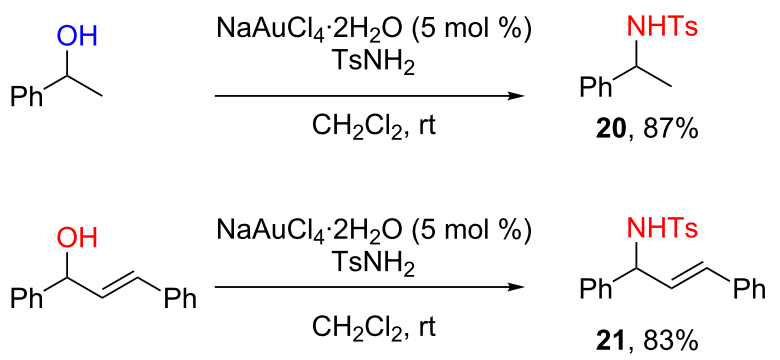

Scheme 9: Scope of 'activated' alcohols in direct substitution reactions.

Shortly after the publication of our seminal results [23], the direct substitution of activated (propargylic, benzylic and allylic) alcohols became of increasing interest and many efficient alternative methods were proposed [40-43]. Among these, great interest has been shown in the use of APTS or iron(III) catalysts due to their low cost and toxicity [26-29]. Despite its high cost, gold catalysis has some intrinsic benefits compared to other reported methodologies. Firstly, these Au(III)-catalyzed substitutions are clean and efficient processes and are usually carried out at room temperature. This point was very nicely illustrated by Dyker: In the reaction of 2,4-dimethoxybenzaldehyde with propargylic alcohol $\mathbf{1 b}$ (Scheme 10), no substitution occurred at room temperature with a stoichiometric amount of $\mathrm{BF}_{3} \cdot \mathrm{Et}_{2} \mathrm{O}$ but was complete with only $1 \mathrm{~mol} \%$ of $\mathrm{AuCl}_{3}$ as catalyst [25].

Secondly, gold(III) possesses $\pi$-acidic properties and is able to activate triple bonds towards the addition of nucleophiles. Thus different reactivities and selectivities might be expected under gold catalysis conditions. For example, it could be interesting to combine both Lewis and $\pi$-acidities to promote domino reactions $[44,45]$.

\section{Domino reactions in the presence of bi-nucleophiles}

We anticipated that by using bi-nucleophiles $\mathrm{HNu}^{1}-\mathrm{Nu}^{2} \mathrm{H}$, the first nucleophilic substitution would be followed by activation of the triple bond and addition of the remaining nucleophilic group to the alkyne (Scheme 11) [63].

Whereas no reaction occurred with bis-protected hydrazines, unexpected reactions occurred with protected $\left(\mathrm{P}=\mathrm{Cbz}, \mathrm{PhSO}_{2}\right)$ hydroxylamines (Scheme 12). In model reactions of propar-<smiles>COc1ccc(C=O)c(OC)c1</smiles>

$\mathrm{AuCl}_{3} 1 \mathrm{~mol} \% 82 \%$ yield $\mathrm{BF}_{3} \cdot \mathrm{Et}_{2} \mathrm{O} 100 \mathrm{~mol} \%<1 \%$ yield

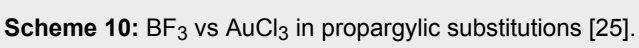

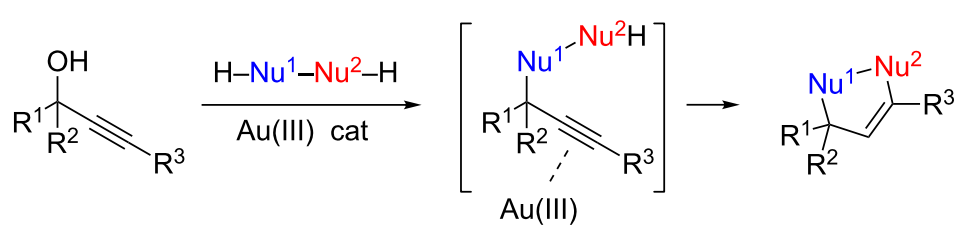


gylic alcohol 1 with $\mathrm{PhSO}_{2} \mathrm{NHOH}$ in the presence of $\mathrm{NaAuCl}_{4}$ neither the propargylic substitution product $\mathbf{2 2}$ nor the expected isoxazoline $\mathbf{2 3}$ could be observed in the crude product. Instead a 1:1 mixture of unreacted alcohol $\mathbf{1}$ and compound $\mathbf{2 4}$ formally resulting from the addition of a second equivalent of hydroxylamine was obtained. By using 2.1 equivalents of the Cbz- or $\mathrm{PhSO}_{2}$-protected hydroxylamines, compounds $\mathbf{2 4 a - c}$ were isolated in $67-79 \%$ yields as single diastereomers. Determination of the structures of $\mathbf{2 4}$ was a challenging task and could only be determined by an X-ray crystal structure determination on compound $24 \mathbf{b}$ [63].
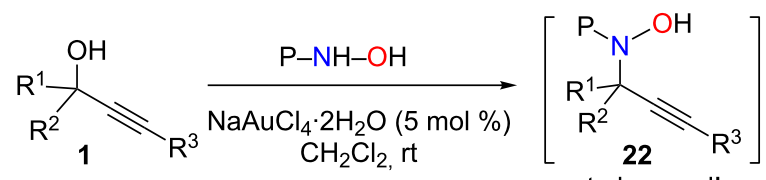
not observed!

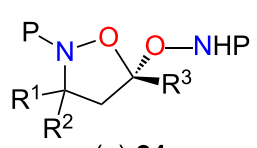

$( \pm)-24$

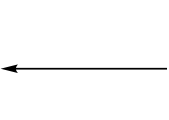

(1)

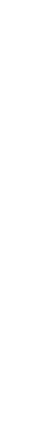

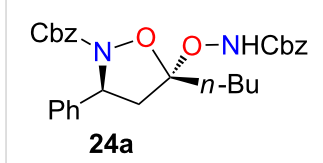

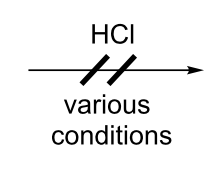

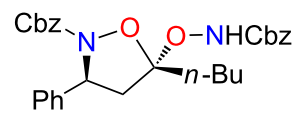

24a<smiles>CCCCCCCCCC(C)(C)C</smiles><smiles>COC(C)C1CCCCC1</smiles><smiles>CO[C@]1([15CH3])CC(c2ccccc2)N(C(=O)OCc2ccccc2)O1</smiles>

$25,68 \%$

Scheme 13: Tentative hydrolysis of bis-adduct 24a.

triple bonds $[64,65]$, we anticipated that its use would lead only to the propargylic substitution product $[28,29]$, and then, by adding a gold(III) catalyst, the cyclization could occur to yield the isoxazolines.

Indeed, in the presence of iron(III) chloride [66-69], the substitution product 22a was obtained in $87 \%$ yield, with no trace of the cyclized product even after prolonged reaction at reflux (Scheme 14). Very recently, Darcel described the iron(III) hydration of terminal alkynes [65]. These conditions were attempted to cyclize 22a but in our hands only extensive decomposition was observed. We thus turned our attention to gold-catalyzed cyclization of 22a which proved more difficult than initially expected (Table 2). As shown in Table 2, different metal salts were tried, and it was found that the best conditions were obtained when gold(III) was used in the presence of a catalytic amount (30 mol \%) of DMAP [70].<smiles>CCCC1(ONS(=O)(=O)c2ccccc2)CC(c2ccccc2)N(OSc2ccccc2)O1</smiles>

24c, $67 \%$

Scheme 12: Tandem reactions from protected hydroxylamines and propargylic alcohols. $\mathrm{P}=\mathrm{Cbz}, \mathrm{PhSO}_{2}$.

Efforts to regenerate isoxazolines 23a from 24a by acidic treatment, under various conditions, were unsuccessful in our hands. Notably, in the presence of $37 \%$ aqueous $\mathrm{HCl}$ in refluxing methanol, the transacetalized product $\mathbf{2 5}$ was isolated in $68 \%$ yield (Scheme 13).

The desired isoxazolines cannot be directly obtained from propargylic alcohols $\mathbf{1}$ in the presence of gold(III) catalysts. From these preliminary experiments, it appears that the addition of hydroxylamine to the isoxazoline double bond is much faster than propargylic substitution. Consequently, the only possibility to obtain these isoxazolines would be to realize the propargylic substitution first of all (and consume all of the hydroxylamine) and subsequently perform the cyclization. Since iron(III) was known to be inefficient in the hydration of

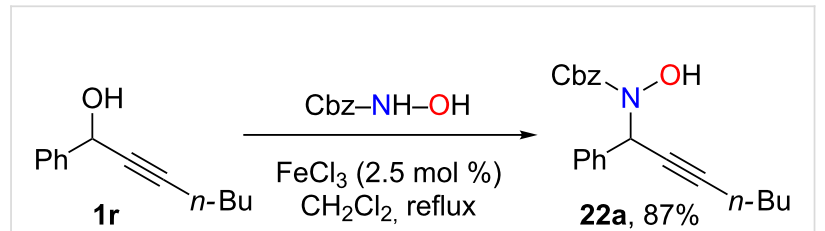

Scheme 14: Iron-catalyzed propargylic substitutions.

We next tried to develop one-pot conditions for the direct transformation of propargylic alcohols $\mathbf{1}$ to isoxazolines 23. Thus, treatment of the propargylic alcohol first of all with $\mathrm{FeCl}_{3}$ to promote the propargylic substitution followed by reaction with $\mathrm{NaAuCl}_{4}$, in the presence of DMAP $30 \mathrm{~mol} \%$, for the cyclization step as outlined in Scheme 15 proved to be efficient and compounds 23a-i were obtained in 38-86\% yield (Scheme 15).

Prompted by the apparently simplicity of the addition of hydroxylamine to the isoxazoline double bond (Scheme 12), we next tried to promote the gold-catalyzed addition of various 
Table 2: Propargylic N-hydroxylamine cyclization

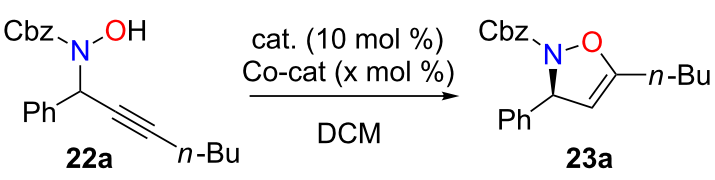

\begin{tabular}{|c|c|c|c|c|}
\hline Entry & $\begin{array}{c}\text { Cat. } \\
(10 \mathrm{~mol} \%)\end{array}$ & $\begin{array}{l}\text { Co-Cat } \\
\text { mol \% }\end{array}$ & $T$ & $\begin{array}{l}\text { Yield } \\
(\%)\end{array}$ \\
\hline 1 & $\mathrm{NaAuCl}_{4} \cdot 2 \mathrm{H}_{2} \mathrm{O}$ & - & rt or reflux & $<20 \%$ \\
\hline 2 & $\mathrm{Ph}_{3} \mathrm{PAuCl}$ & - & rt or reflux & - \\
\hline 3 & $\mathrm{Ph}_{3} \mathrm{PAuCl} / \mathrm{AgOTf}$ & - & reflux & 8 \\
\hline 4 & $\mathrm{Znl}_{2}$ & $\begin{array}{c}\text { DMAP } \\
30\end{array}$ & rt or reflux & $15-20$ \\
\hline 5 & $\mathrm{FeCl}_{3}$ & $\begin{array}{c}\text { DMAP } \\
30\end{array}$ & reflux & - \\
\hline 6 & $\mathrm{NaAuCl}_{4} \cdot 2 \mathrm{H}_{2} \mathrm{O}$ & $\begin{array}{c}\text { DMAP } \\
30\end{array}$ & reflux & 84 \\
\hline
\end{tabular}
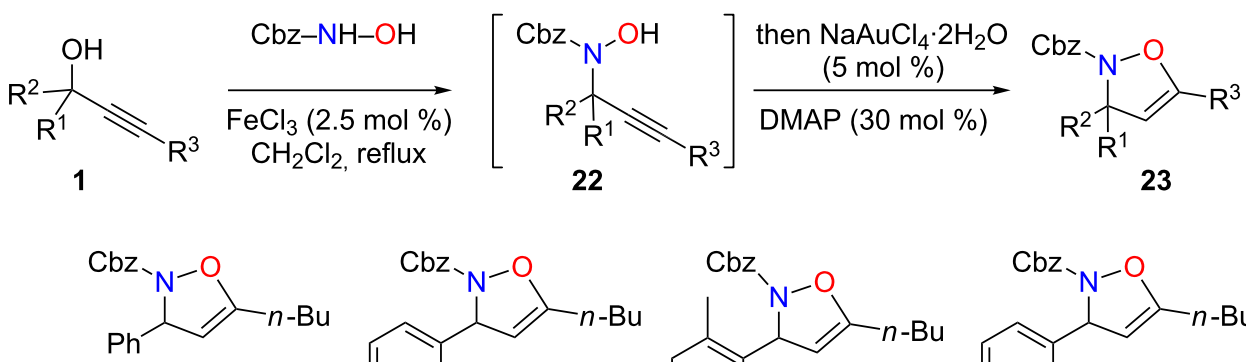

$23 a, 79 \%$

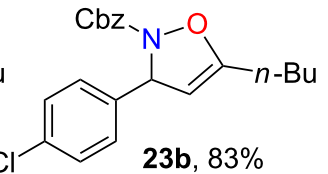<smiles>CCCCPC1=CC(c2ccccc2C)N(C(=O)OC(C)(C)C)O1</smiles>

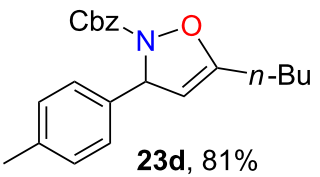<smiles>COc1ccc(C2C=C(PCC(C)(C)C)ON2C(=O)OCc2ccccc2)cc1</smiles><smiles>CCCCPC1=CC(c2cccs2)N(C(=O)OC(C)(C)C)O1</smiles><smiles>CCC(C)C[Te]C1=CC(c2ccccc2)N(C(=O)OC(C)(C)C)O1</smiles>

$23 g, 79 \%$<smiles>O=C(c1ccccc1)N1OC(CCc2ccccc2)=CC1c1ccccc1</smiles>

$23 \mathrm{~h}, 79 \%$

Scheme 15: Isoxazolines formation

nucleophiles. As illustrated in Scheme 16, the reaction proved restricted to alcohols and no reaction occurred with $\mathrm{TsNH}_{2}$ or electron-rich aromatic compounds such as 1,3-dimethoxybenzene.

Some contradictions arose from these experiments. On one hand, when propargylic alcohols $\mathbf{1}$ and protected hydroxylamines were treated with gold catalyst at room temperature (Scheme 12), the reactions were rapid and led to the formation of 24. On the other hand, when trying to perform gold-catalyzed cyclization of the isolated propargylic substitution product $\mathbf{2 2}$, the reaction appeared to be difficult and required the addition of a co-catalytic amount of DMAP, under reflux conditions, to be effective. Moreover, it has been shown that oxygen nucleophiles are prone to attack at the acetylenic site. Thus the reaction pathway could proceed in one of two ways: First, propargylic substitution by the nitrogen of the nucleophile followed by the cyclization (Scheme 17, path A) or attack on the acetylenic position by the oxygen of the nucleophile followed by intramolecular propargylic substitution (Scheme 17, path B). 


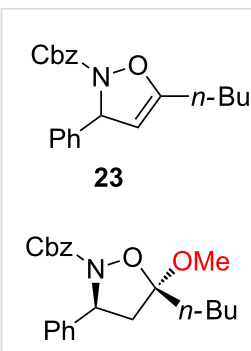

$25,60 \%$

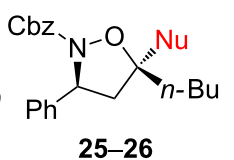

25-26<smiles>COc1ccc([C@]2(OC(=O)c3ccccc3)C[C@H](c3ccccc3)N(C(=O)OCc3ccccc3)O2)c(OC)c1</smiles>

28, not observed

(recovered SM 23)

\section{Scheme 16: Addition of nucleophiles to isoxazolines.}

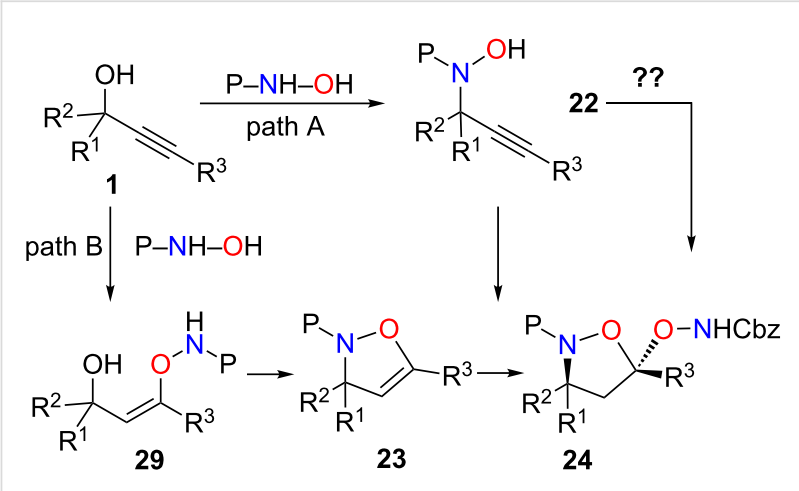

Scheme 17: Potential mechanistic pathways

The determination of the reaction pathway is a challenging task and to gain more insight we designed a model substrate $\mathbf{3 0}$ bearing a methoxy group in a quaternary substituted propargylic position and a (nucleophilic) alcohol function in the homopropargylic position. In order to deactivate the triple bond toward nucleophilic addition, a TMS group was placed in the acetylenic position. This substrate, obtained from the addition of an allenyl(cyano)cuprate on butyraldehyde [71-73], was reacted with allyltrimethylsilane. The reaction was totally regioselective for the propargylic site. Different reaction paths can be expected: i) The formation of a propargylic carbocation that can be attacked by allyltrimethylsilane or vicinal hydroxy group and ii) homopropargylic alcohol attack on the triple bond. The only product that could be isolated was the furan $\mathbf{3 1}$ which was obtained in $78 \%$ yield, with no trace of any product arising from an allylsilane attack (Scheme 18). The formation of the furan might be explained by a direct attack of the homopropargylic alcohol on the triple bond or a gold-catalyzed rearrangement of a transient epoxide as recently described by Blanc and Pale [74-76].

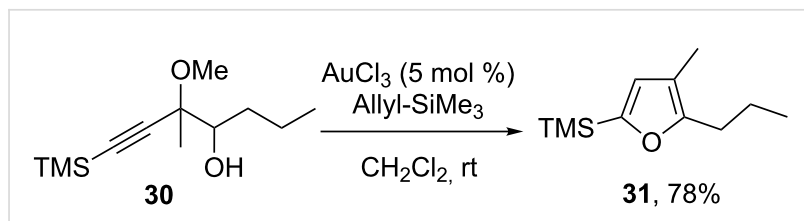

Scheme 18: Synthesis of furans from homoproargylic alcohols.

\section{Synthetic developments}

This result prompted us to explore the synthesis of functionalized furans from various homopropargylic alcohols obtained on a multi-gram scale, by our recently described allenylcuprate chemistry [71-73]. In the meantime, Aponick [77] and Akai [78] described very similar results using $\mathrm{Au}(\mathrm{I}) / \mathrm{Ag}(\mathrm{I})$ catalysts. Some of our gold(III)-catalyzed reactions are illustrated in Scheme 19. Interestingly, when the homopropargylic alcohol is protected as a MOM ether, a mixture of furans resulting from proto-demetallation 35 and MOM transfer 36 was obtained in a 75:25 ratio, respectively, whereas in the presence of gold(I) catalyst the proto-demetallation product $\mathbf{3 5}$ was the sole product. For related cyclization with subsequent migration of the ether substituent, see [79] and references therein. This experiment further highlights the strong propensity of oxygen nucleophiles for the addition to gold activated triple bonds.<smiles>COC(C#Cc1ccccc1)C(O)CCPc1ccc(-c2ccccc2)o1</smiles>

32

$33,85 \%$
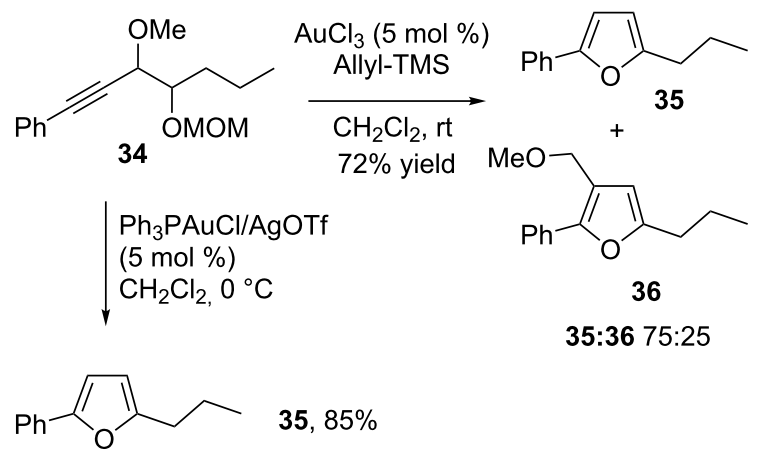

$35,85 \%$

From allylated substitution products $\mathbf{2}$, we were also able to develop two synthetic applications. In an one-pot, sequential, reaction with first a gold(III)-catalyzed propargylic substitution followed by a gold(I)-catalyzed cycloisomerization, the bicyclic compound 37 was obtained in $71 \%$ yield [24,80-82]. Very recently, a remarkable one-pot reaction using an original gold(III) catalyst has been described by Fairlamb [82]. We were 


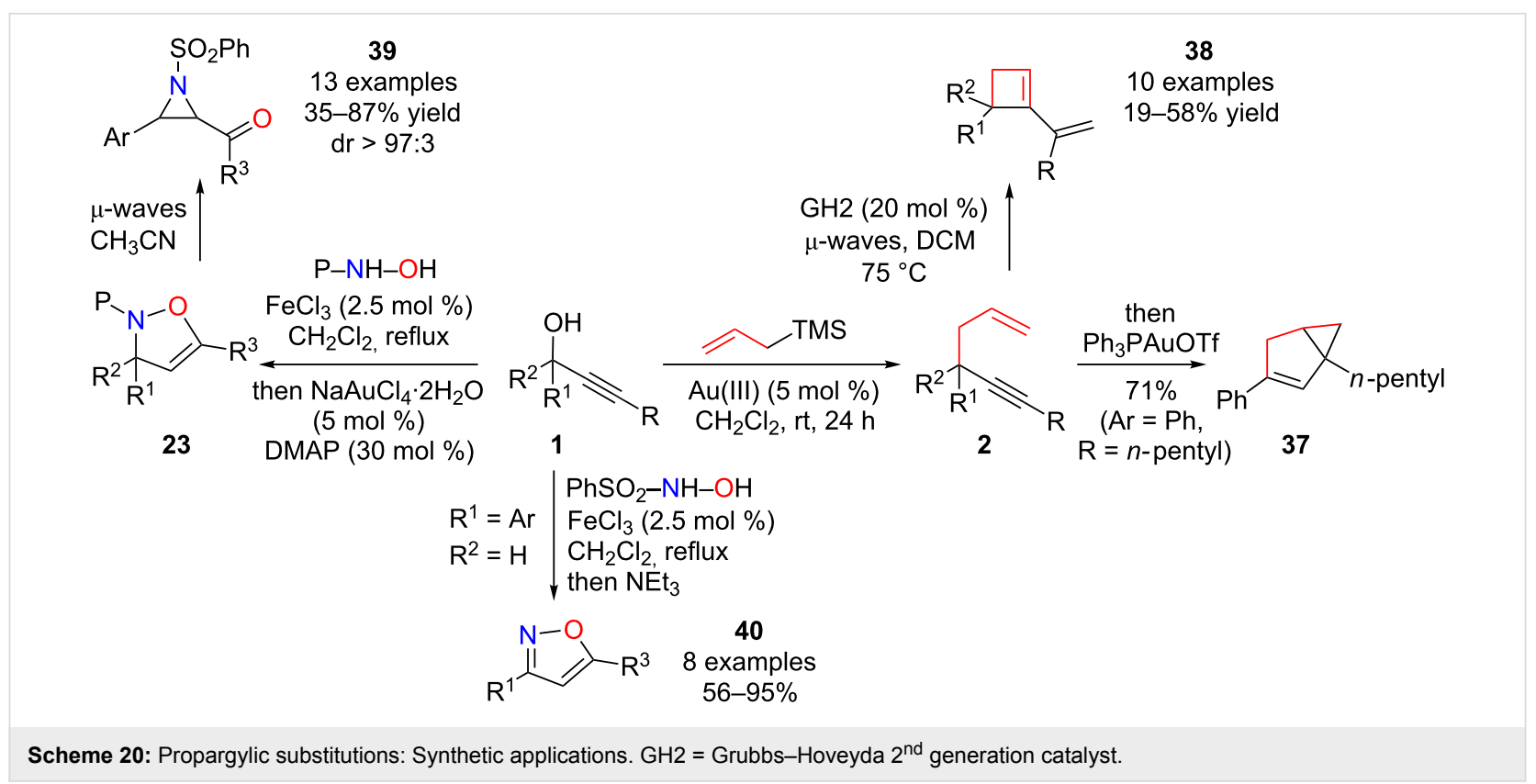

also able, from compound $\mathbf{2}$, to develop a 1,5-enyne metathesis that leads to functionalized cyclobutenes 38 (Scheme 20) [83], which was subsequently nicely illustrated by Goess in a total synthesis of grandisol [84].

From isoxazolines $\mathbf{2 3}$, we were also able to promote, under micro-waves irradiation, a Baldwin rearrangement to yield the cis-acylaziridines 39, with high diastereoselectivity [85]. Finally, from propargylic alcohols 1, a sequential iron(III)catalyzed propargylic substitution $[28,29]$ followed by a $\mathrm{NEt}_{3}-$ mediated elimination of the sulfonyl group and oxime cyclization gave, in a one-pot sequence, the corresponding isoxazoles $\mathbf{4 0}$ in good yields (Scheme 20) [86].

\section{Conclusion}

In conclusion, we have developed gold(III)-catalyzed direct propargylic (allylic, benzylic) substitutions which have proved efficient with a great number of nucleophiles under mild conditions (dichloromethane, room temperature). A notable limitation of this methodology is since a stabilized positive charge is involved the scope of the reaction is limited to the use of tertiary or benzylic (allylic) propargylic alcohols. On the other hand, such a mechanism also implies that in the presence of chiral gold catalyst, through coordination to the triple bond (Scheme 1), enantioselective transformations could be obtained. We also found that with chiral gold(III) complexes very deceiving results can be obtained. It is worth noting that, recently, Bandini described very impressive enantioselective intramolecular direct allylic substitutions using chiral gold(I) complexes $[87,88]$. We also took advantage of the $\pi$ - and $\sigma$-(Lewis) acidities of gold(III) complexes to promote domino reactions with bi-nucleophiles such as protected hydroxylamines. In the presence of gold(III), the expected isoxazolines $\mathbf{2 3}$ could not be directly obtained but required a dual iron(III)/ gold(III) catalysis to be effective. Nevertheless, gold catalysts exert interesting $\pi$ - and $\sigma$-Lewis properties, allowing direct nucleophilic substitution of various di or tri-substituted alcohols and cyclization reactions under mild conditions. This methodology gives easy access to various elaborated molecules with varied functionalities, as illustrated in this account.

\section{Acknowledgements}

We are grateful to the CNRS for financial support (ATIPE jeune équipe), the Institut de Chimie des Substances Naturelles (Gif sur Yvette), the MESR (E. G. Ph.D. grant) and the Ecole Nationale Supérieure de Chimie de Montpellier.

\section{References}

1. Constable, D. J. C.; Dunn, P. J.; Hayler, J. D.; Humphrey, G. R.; Leazer, J. L.; Linderman, R. J.; Lorenz, K.; Manley, J.; Pearlman, B. A.; Wells, A.; Zaks, A.; Zhang, T. Y. Green Chem. 2007, 9, 411-420. doi:10.1039/b703488c

2. Bandini, M.; Tragni, M. Org. Biomol. Chem. 2009, 7, 1501-1507. doi:10.1039/b823217b

3. Emer, E.; Sinisi, R.; Capdevila, M. G.; Petruzziello, D.; De Vincentiis, F.; Cozzi, P. G. Eur. J. Org. Chem. 2011, 647-666. doi:10.1002/ejoc.201001474

4. Cozzi, P. G.; Benfatti, F. Angew. Chem., Int. Ed. 2010, 49, 256-259. doi:10.1002/anie.200905235

5. Bisaro, F.; Prestat, G.; Vitale, M.; Poli, G. Synlett 2002, 1823-1826. doi:10.1055/s-2002-34884

6. Olah, G. A.; Krishnamurti, R.; Survya Prakash, G. K. J. Org. Chem. 1990, 55, 6061-6062. doi:10.1021/jo00311a029 And references cited therein. 
7. Nicholas, K. M. Acc. Chem. Res. 1987, 20, 207-214. doi:10.1021/ar00138a001

8. Imada, Y.; Yuasa, M.; Nakamura, I.; Murahashi, S.-I. J. Org. Chem 1994, 59, 2282-2284. doi:10.1021/jo00088a004

9. Hattori, G.; Matsuzawa, H.; Miyake, Y.; Nishibayashi, Y. Angew. Chem., Int. Ed. 2008, 47, 3781-3783. doi:10.1002/anie. 200800276 See for asymmetric versions

10. Detz, R. J.; Delville, M. M. E.; Hiemstra, H.; van Maarseveen, J. H. Angew. Chem., Int. Ed. 2008, 47, 3777-3780. doi:10.1002/anie.200705264

11. Nishibayashi, Y.; Uemura, S. Curr. Org. Chem. 2006, 10, 135-150. doi:10.2174/138527206775192960

12. Nishibayashi, Y.; Milton, M. D.; Inada, Y.; Yoshikawa, M.; Wakiji, I.; Hidai, M.; Uemura, S. Chem.-Eur. J. 2005, 11, 1433-1451. doi:10.1002/chem.200400833

13. Yamauchi, Y.; Onodera, G.; Sakata, K.; Yuki, M.; Miyake, Y.; Uemura, S.; Nishibayashi, Y. J. Am. Chem. Soc. 2007, 129, 5175-5179. doi:10.1021/ja0687926

14. Matsuzawa, H.; Kanao, K.; Miyake, Y.; Nishibayashi, Y. Org. Lett. 2007, 9, 5561-5564. doi:10.1021/ol7025203

15. Ammal, S. C.; Yoshikai, N.; Inada, Y.; Nishibayashi, Y.; Nakamura, E. J. Am. Chem. Soc. 2005, 127, 9428-9438. doi:10.1021/ja050298z

16. Matsuzawa, H.; Miyake, Y.; Nishibayashi, Y. Angew. Chem., Int. Ed. 2007, 46, 6488-6491. doi:10.1002/anie.200701261

17. Nishibayashi, Y.; Shinoda, A.; Miyake, Y.; Matsuzawa, H.; Sato, M. Angew. Chem., Int. Ed. 2006, 45, 4835-4839. doi:10.1002/anie.200601181

18. Inada, Y.; Nishibayashi, Y.; Uemura, S. Angew. Chem., Int. Ed. 2005, 44, 7715-7717. doi:10.1002/anie.200502981

19. Ohri, R. V.; Radosevich, A. T.; Hrovat, K. J.; Musich, C.; Huang, D.; Holman, T. R.; Toste, F. D. Org. Lett. 2005, 7, 2501-2504. doi:10.1021/ol050897a

20. Sherry, B. D.; Radosevich, A. T.; Toste, F. D. J. Am. Chem. Soc. 2003 , 125, 6076-6077. doi:10.1021/ja0343050

21. Kennedy-Smith, J. J.; Young, L. A.; Toste, F. D. Org. Lett. 2004, 6, 1325-1327. doi:10.1021/ol049649p

22. Kuninobu, Y.; Ishii, E.; Takai, K. Angew. Chem., Int. Ed. 2007, 46, 3296-3299. doi:10.1002/anie.200700183

23. Georgy, M.; Boucard, V.; Campagne, J.-M. J. Am. Chem. Soc. 2005, 127, 14180-14181. doi:10.1021/ja0534147

24. Georgy, M.; Boucard, V.; Debleds, O.; Dal Zotto, C.; Campagne, J.-M. Tetrahedron 2009, 65, 1758-1766. doi:10.1016/j.tet.2008.12.051

25. Liu, J.; Muth, E.; Flörke, U.; Henkel, G.; Merz, K.; Sauvageau, J.; Schwake, E.; Dyker, G. Adv. Synth. Catal. 2006, 348, 456-462. doi:10.1002/adsc.200505411

26. Sanz, R.; Martínez, A.; Álvarez-Gutiérrez, J. M.; Rodríguez, F. Eur. J. Org. Chem. 2006, 1383-1386. doi:10.1002/ejoc.200500960

27. Sanz, R.; Miguel, D.; Martínez, A.; Álvarez-Gutiérrez, J. M.; Rodríguez, F. Org. Lett. 2007, 9, 727-730. doi:10.1021/ol0631298

28. Zhan, Z.-P.; Yu, J.-L.; Liu, H.-J.; Cui, Y.-Y.; Yang, R.-F.; Yang, W.-Z.; Li, J.-P. J. Org. Chem. 2006, 71, 8298-8301. doi:10.1021/jo061234p

29. Ji, W.-H.; Pan, Y.-M.; Zhao, S.-Y.; Zhan, Z.-P. Synlett 2008, 3046-3052. doi:10.1055/s-0028-1087344

30. Yadav, J. S.; Reddy, B. V. S.; Rao, T. S.; Rao, K. V. R. Tetrahedron Lett. 2008, 49, 614-618. doi:10.1016/j.tetlet.2007.11.143

31. Hui, H.-H.; Zhao, Q.; Yang, M.-Y.; She, D.-B.; Chen, M.; Huang, G.-S. Synthesis 2008, 191-196. doi:10.1055/s-2007-990951

32. Lee, K.; Lee, P. H. Org. Lett. 2008, 10, 2441-2444. doi:10.1021/ol800719g
33. Yadav, J. S.; Reddy, B. V. S.; Rao, K. V. R.; Kumar, G. G. K. S. N. Synthesis 2007, 3205-3210. doi:10.1055/s-2007-990797

34. Zhan, Z.-P.; Yang, W.-Z.; Yang, R.-F.; Yu, J.-L.; Li, J.-P.; Liu, H.-J. Chem. Commun. 2006, 3352-3354. doi:10.1039/b606470a

35. Qin, H.; Yamagiwa, N.; Matsunaga, S.; Shibasaki, M. Angew. Chem., Int. Ed. 2007, 46, 409-413. doi:10.1002/anie.200602909

36. Yadav, J. S.; Reddy, B. V. S.; Rao, K. V. R.; Kumar, G. G. K. S. N. Tetrahedron Lett. 2007, 48, 5573-5576. doi:10.1016/j.tetlet.2007.04.056

37. Huang, W.; Wang, J.; Shen, Q.; Zhou, X. Tetrahedron 2007, 63, 11636-11643. doi:10.1016/j.tet.2007.08.114

38. Srihari, P.; Reddy, J. S. S.; Bhunia, D. C.; Mandal, S. S.; Yadav, J. S. Synth. Commun. 2008, 38, 1448-1455. doi:10.1080/00397910801914335

39. Srihari, P.; Bhunia, D. C.; Sreedhar, P.; Mandal, S. S.; Reddy, J. S. S.; Yadav, J. S. Tetrahedron Lett. 2007, 48, 8120-8124. doi:10.1016/j.tetlet.2007.09.123

40. Kabalka, G. W.; Yao, M.-L. Curr. Org. Synth. 2008, 5, 28-32. doi:10.2174/157017908783497536

41. Miyake, Y.; Uemura, S.; Nishibayashi, Y. ChemCatChem 2009, 1, 342-356. doi:10.1002/cctc.200900214

42. Detz, R. J.; Hiemstra, H.; van Maarseveen, J. H. Eur. J. Org. Chem. 2009, 6263-6276. doi:10.1002/ejoc.200900877

43. Ljungdahl, N.; Kann, N. Angew. Chem., Int. Ed. 2009, 48, 642-644. doi:10.1002/anie.200804114

44. Alfonsi, M.; Arcadi, A.; Aschi, M.; Bianchi, G.; Marinelli, F. J. Org. Chem. 2005, 70, 2265-2273. doi:10.1021/jo047793i

45. Iritani, K.; Matsubara, S.; Utimoto, K. Tetrahedron Lett. 1988, 29, 1799-1802. doi:10.1016/S0040-4039(00)82047-X

46. Corma, A.; Leyva-Pérez, A.; Sabater, M. J. Chem. Rev. 2011, 111, 1657-1712. doi:10.1021/cr100414u

47. Li, Z.; Brouwer, C.; He, C. Chem. Rev. 2008, 108, 3239-3265. doi:10.1021/cr068434l

48. Hashmi, A. S. K. Chem. Rev. 2007, 107, 3180-3211. doi:10.1021/cr000436x

49. Fukuda, Y.; Utimoto, K. Bull. Chem. Soc. Jpn. 1991, 64, 2013-2015. doi:10.1246/bcsj.64.2013

50. Fukuda, Y.; Utimoto, K. J. Org. Chem. 1991, 56, 3729-3731. doi:10.1021/jo00011a058

51. Egi, M.; Yamaguchi, Y.; Fujiwara, N.; Akai, S. Org. Lett. 2008, 10, 1867-1870. doi:10.1021/ol800596c

52. Ramón, R. S.; Marion, N.; Nolan, S. P. Tetrahedron 2009, 65, 1767-1773. doi:10.1016/j.tet.2008.10.111

53. Pennell, M. N.; Unthank, M. G.; Turner, P.; Sheppard, T. D. J. Org. Chem. 2011, 76, 1479-1482. doi:10.1021/jo102263t

54. Engel, D. A.; Dudley, G. B. Org. Lett. 2006, 8, 4027-4029. doi:10.1021/ol0616743

55. Haug, T. T.; Harschneck, T.; Duschek, A.; Lee, C.-U.; Binder, J. T.; Menz, H.; Kirsch, S. F. J. Organomet. Chem. 2009, 694, 510-514. doi:10.1016/j.jorganchem.2008.09.062

56. Wang, W.; Xu, B.; Hammond, G. B. J. Org. Chem. 2009, 74, 1640-1643. doi:10.1021/jo802450n

57. Arcadi, A.; Alfonsi, M.; Chiarini, M.; Marinelli, F. J. Organomet. Chem. 2009, 694, 576-582. doi:10.1016/j.jorganchem.2008.12.013

58. Maraval, V.; Duhayon, C.; Coppel, Y.; Chauvin, R. Eur. J. Org. Chem. 2008, 5144-5156. doi:10.1002/ejoc.200800711

59. Guo, S.; Song, F.; Liu, Y. Synlett 2007, 964-968. doi:10.1055/s-2007-973865 
60. Rao, W.; Chan, P. W. H. Org. Biomol. Chem. 2008, 6, 2426-2433. doi:10.1039/b805067h

61. Mertins, K.; lovel, I.; Kischel, J.; Zapf, A.; Beller, M. Adv. Synth. Catal. 2006, 348, 691-695. doi:10.1002/adsc.200505433

62. Cuenca, A. B.; Mancha, G.; Asensio, G.; Medio-Simón, M. Chem.-Eur. J. 2008, 14, 1518-1523. doi:10.1002/chem.200701134

63. Debleds, O.; Dal Zotto, C.; Vrancken, E.; Campagne, J.-M.; Retailleau, P. Adv. Synth. Catal. 2009, 351, 1991-1998. doi:10.1002/adsc.200900127

64. Hintermann, L.; Labonne, A. Synthesis 2007, 1121-1150. doi:10.1055/s-2007-966002

65. Wu, X.-F.; Bezier, D.; Darcel, C. Adv. Synth. Catal. 2009, 351, 367-370. doi:10.1002/adsc.200800666

66. Michaux, J.; Terrasson, V.; Marque, S.; Wehbe, J.; Prim, D.; Campagne, J.-M. Eur. J. Org. Chem. 2007, 2601-2603. doi:10.1002/ejoc.200700023

67. Dal Zotto, C.; Wehbe, J.; Virieux, D.; Campagne, J.-M. Synlett 2008, 2033-2035. doi:10.1055/s-2008-1077954

68. Dal Zotto, C.; Virieux, D.; Campagne, J.-M. Synlett 2009, 276-278. doi:10.1055/s-0028-1087664

69. Dal Zotto, C.; Michaux, J.; Zarate-Ruiz, A.; Gayon, E.; Virieux, D.; Campagne, J.-M.; Terrasson, V.; Pieters, G.; Gaucher, A.; Prim, D. J. Organomet. Chem. 2011, 696, 296-304. doi:10.1016/j.jorganchem.2010.09.031

70. Aschwanden, D.; Frantz, D. E.; Carreira, E. M. Org. Lett. 2000, 2, 2331-2333. doi:10.1021/ol006095r

71. Bernaud, F.; Vrancken, E.; Mangeney, P. Org. Lett. 2003, 5, 2567-2569. doi:10.1021/ol034893m

72. Vrancken, E.; Alouane, N.; Gérard, H.; Mangeney, P. J. Org. Chem. 2007, 72, 1770-1779. doi:10.1021/jo062344z

73. Alouane, N.; Vrancken, E.; Mangeney, P. Synthesis 2007, 1261-1264. doi:10.1055/s-2007-965969

74. Cordonnier, M.-C.; Blanc, A.; Pale, P. Org. Lett. 2008, 10, 1569-1572. doi:10.1021/ol800219k

75. Blanc, A.; Tenbrink, K.; Weibel, J.-M.; Pale, P. J. Org. Chem. 2009, 74, 5342-5348. doi:10.1021/jo9008172

76. Blanc, A.; Alix, A.; Weibel, J.-M.; Pale, P. Eur. J. Org. Chem. 2010, 1644-1647. doi:10.1002/ejoc.200901331

77. Aponick, A.; Li, C.-Y.; Malinge, J.; Marques, E. F. Org. Lett. 2009, 11, 4624-4627. doi:10.1021/ol901901m

78. Egi, M.; Azechi, K.; Akai, S. Org. Lett. 2009, 11, 5002-5005. doi:10.1021/ol901942t

79. Ueda, M.; Sato, A.; Ikeda, Y.; Miyoshi, T.; Naito, T.; Miyata, O. Org. Lett. 2010, 12, 2594-2597. doi:10.1021/ol100803e

80. Luzung, M. R.; Markham, J. P.; Toste, F. D. J. Am. Chem. Soc. 2004, 126, 10858-10859. doi:10.1021/ja046248w

81. Sanz, R.; Martínez, A.; Miguel, D.; Álvarez-Gutiérrez, J. M.; Rodríguez, F. Synthesis 2007, 3252-3256. doi:10.1055/s-2007-983831

82. Reeds, J. P.; Whitwood, A. C.; Healy, M. P.; Fairlamb, I. J. S. Chem. Commun. 2010, 46, 2046-2048. doi:10.1039/b925919h

83. Debleds, O.; Campagne, J.-M. J. Am. Chem. Soc. 2008, 130, 1562-1563. doi:10.1021/ja0780986

84. Graham, T. J. A.; Gray, E. E.; Burgess, J. M.; Goess, B. C. J. Org. Chem. 2010, 75, 226-228. doi:10.1021/jo9020375

85. Gayon, E.; Debleds, O.; Nicouleau, M.; Lamaty, F.; van der Lee, A.; Vrancken, E.; Campagne, J.-M. J. Org. Chem. 2010, 75, 6050-6053. doi:10.1021/jo101273d

86. Debleds, O.; Gayon, E.; Ostaszuk, E.; Vrancken, E.; Campagne, J.-M. Chem.-Eur. J. 2010, 16, 12207-12213. doi:10.1002/chem.201001461
87. Bandini, M.; Eichholzer, A. Angew. Chem., Int. Ed. 2009, 48, 9533-9537. doi:10.1002/anie.200904388

88. Bandini, M.; Monari, M.; Romaniello, A.; Tragni, M. Chem.-Eur. J. 2010, 16, 14272-14277. doi:10.1002/chem.201002606

\section{License and Terms}

This is an Open Access article under the terms of the Creative Commons Attribution License

(http://creativecommons.org/licenses/by/2.0), which permits unrestricted use, distribution, and reproduction in any medium, provided the original work is properly cited.

The license is subject to the Beilstein Journal of Organic Chemistry terms and conditions:

(http://www.beilstein-journals.org/bjoc)

The definitive version of this article is the electronic one which can be found at: doi:10.3762/bjoc.7.99 